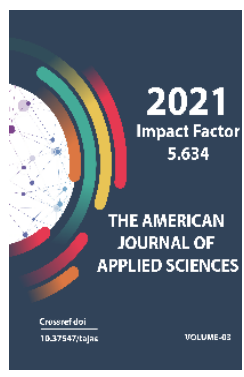

\title{
Methodological Approaches To Analysis Of The Food Industry Cost Chain And Estimation Of Its Efficiency
}

G'ayratbek Mahamadyusupovich Mamasoliev

Senior Lecturer, Department Of Economics, Andijan State University, Uzbekistan

Journal Website:

http://usajournalshub.c om/index,php/tajas

Copyright: Original content from this work may be used under the terms of the creative commons attributes 4.0 licence.

\section{ABSTRACT}

In this article commented methodological approaches on analysis of value chain, and highlighted an aim and tasks of the methods of analysis, besides developed recommendations about using them on practice.

\section{KEYWORDS}

Value chain, competition, production resources, analysis, economic policy.

\section{INTRODUCTION}

Scientific approaches to the management of competitiveness in the food industry are being enriched on the basis of new data. The reason for this is an attempt to study the competition based on its results and a correct assessment of the current situation in the industry. To clarify the essence of the problem, the following question is posed: why are the prices of food products sold on the store shelves high and they are growing, while payments made to suppliers of primary raw materials, that is, farmers and households, are significantly low? 
This situation is also typical for the food industry in Uzbekistan, since every year there are fluctuations in the prices of food products and they often change in the direction of growth.

The purpose of this article is to compare two methodological approaches to the study of competitiveness in the food industry by comparing methods of analysis, as well as to develop proposals for their application in practice through the synergy of the most important and useful methods.

\section{ANALYSIS OF THE LITERATURE}

To study the above-mentioned problem, specialists pay attention to the study of the competitive environment in the context of the country's territories, or to such effects as an increase in the number of producers and market concentration. Observing the dynamics of market prices makes it possible to clarify many issues regarding the competitive environment where manufacturers operate. Analysis of scientific literature shows that new approaches and methods are being developed to study the competitive situation in the market, however, in some situations, researchers consider it appropriate to use those methods that are well known to many in science.

Management of competitiveness in the value chain in the scientific literature is closest to the theory of "institutional economics" and research in this area was started back in the $30 \mathrm{~s}$ of the last century. One of the founders of the concept of "Institutional Economics" R. Coase in 1937 analyzed vertical integration structures when studying the activities of firms. R. Coase analyzed the market situation, in which how firms communicate with each other in the use of available resources in the market and described their behavior [1]. That is, R. Coase's theory showed how firms effectively operate in the market and generate growth. Later, one of the representatives of the theory of "new institutional economics" O. Williamson in 1971 enriched the views of $\mathrm{R}$. Coase in his works, that is, he revealed the essence of the process of the internal organization of production and the peculiarities of its relationship with the market [2]. S. Grosman in 1986 studied those market situations that prevent firms from achieving the optimal level of investment in production and explained their reasons [3]. In addition, the research works of P. Yaaskov and $M$. Porter reflect new facts concerning the problems of firms' competitiveness in the market at the end of the gos of the twentieth century.

Summarizing the above facts, we can say the following opinions: the analysis of competitiveness in the value chain of the food industry is a relatively complex process. This is due to the geographic location of product manufacturers, the competitive market environment, and the scale and specialization of supplier firms. The generally accepted approach of the research community is the fact that the methodological approaches to studying market concentration, the desire to oust competitors and join them to oneself are also applicable to the food industry. However, for the study of retail trade, more in-depth and specific methods of analysis will be needed. Below, we will outline two methodological approaches that were selected for studying the competitive environment in the food industry value chain and proposals for their application in practice. 
The American Journal of Applied sciences

(ISSN - 2689-0992)

Published: April 30, 2021 | Pages: 138-144

Methodological approaches to the problem. The Canadian Institute of Management Accountants, together with researcher J. J. San Miguel, developed a special methodological guide for conducting value chain analysis and commented on its approach in the following way. The specialists of this institute described their approach to managing the competitive environment in the value chain as follows: "competitiveness is not a desire to gain advantages in price and quality of a product relative to competitors, but the excess of the level of consumer satisfaction with a product is greater than expected" [4]. This approach is well thought out and it pays attention when studying the value chain to link the analysis to the goals and objectives of the company or

Table 1

An approach to study value creation participants ${ }^{1}$

\begin{tabular}{|l|l|l|}
\hline № & Group 1: factors that form the structure of value in the chain. \\
\hline 1 & Scale & $\begin{array}{l}\text { How big is the investment in production, research, } \\
\text { marketing and other resources? }\end{array}$ \\
\hline 3 & Experience and study & $\begin{array}{l}\text { How high is the level of vertical integration and can } \\
\text { horizontal integration be used? }\end{array}$ \\
\hline 4 & Technology & $\begin{array}{l}\text { How often does a company turn to best practices and } \\
\text { know-how? }\end{array}$ \\
\hline 5 & Complexity & $\begin{array}{l}\text { What type of technology is used at each stage of the value } \\
\text { chain of the enterprise? }\end{array}$ \\
\hline $\mathbf{N}$ o & Group 2: The formation of a value structure for the execution of operations in the chain. \\
\hline 1 & Participation of workers. & $\begin{array}{l}\text { Are the workers of the enterprise involved in the decision- } \\
\text { offered to consumers? } \\
\text { making process to improve the activities of the enterprise? }\end{array}$ \\
\hline 2 & $\begin{array}{l}\text { Total quality management. } \\
\text { Are managers and workers responsible for product quality } \\
\text { equally? }\end{array}$ \\
\hline 3 & $\begin{array}{l}\text { The workload of production } \\
\text { facilities. }\end{array}$ & $\begin{array}{l}\text { What is the volume of production capacity of the } \\
\text { enterprises according to the plan? }\end{array}$ \\
\hline
\end{tabular}

\footnotetext{
${ }^{1}$ Joseph G. San Miguel. (1996). Value chain analysisi for assesing competetive advantage. Practice on Management accounting. Statement of management accountants. Exhibit-3. Process cost drivers. 10 page. www.imanet.org
} 


\begin{tabular}{|l|l|l|}
\hline 4 & $\begin{array}{l}\text { The efficiency of the company's } \\
\text { production activities. }\end{array}$ & $\begin{array}{l}\text { How efficient is the company's production activity } \\
\text { compared to the established norm? }\end{array}$ \\
\hline 5 & Product configuration. & Is the design and shape of the product effective? \\
\hline 6 & $\begin{array}{l}\text { Communication with suppliers } \\
\text { and consumers. }\end{array}$ & $\begin{array}{l}\text { Does the relationship with the company's suppliers and } \\
\text { customers really work according to the value chain? }\end{array}$ \\
\hline
\end{tabular}

Another scientific approach that deserves attention to study competition in the value chain belongs to the specialists of the UN "FAO". The work of FAO specialists is a kind of conceptual methodological tool for studying the value chain in the food industry on a global scale [7]. According to FAO experts, when studying competition policy problems, attention should be paid to the following points:

a) The study and assessment of factors that influence the state of the value chain, such as: economic, social and environment;

b) Finding the shortcomings of the value chain and developing measures to eliminate them, that is, making changes to the policy;

c) Assessment of the influence of economic, social and environmental factors on the choice and consumption of resources.

Based on the above methods of analysis, the information obtained will serve as a basis for improving policies regarding market entities that compete with each other and experience its influence.

Approach to problem analysis. If you consider the value chain as a sequence of operations closely interconnected with each other, then you should consider it from different points of view to understand how the value chains are so well interconnected with each other. FAO's approach helps identify value chains and develop measures to address them. The analysis method is in fact very similar to the "SWOT" analysis. The analysis is supposed to be carried out in the following areas:

A) Socio-economic analysis of the value chain. The analysis of this complex involves the study of the following elements of the value chain: the macroeconomic and social situation in the country where the value chain operates. That is, an answer should be found to the question - how do these factors affect the activity of the value chain?

B) Demand for value chain results. In this complex value chain analysis, attention should be paid to the specifics on the part of the consumer. Should be considered current and future demand for goods produced by participants in the value chain, their tasks, prices, etc.;

C) Analysis of the institutional environment. The analysis of this complex of the value chain provides for the study and assessment of the mutual relations of the participants in the value chain. Participants can be enterprises, intermediaries, government organizations, infrastructure facilities, etc. As a result of the analysis, a weak link in the chain is identified and recommendations are developed for the state authorities with the aim of making changes in government policy.

D) Analysis of the market for production resources. The analysis of this complex should be carried out to assess the 
activities of market agents and institutions. At this stage of the analysis, market laws are analyzed, their effectiveness, and recommendations for the state are developed. Collection of complete and reliable information about the market, segments and existing monopolies is required. Their impact on the value chain is assessed;

E) Functional analysis of the value chain. Functional analysis provides detailed information about the structure of the industry, about its production technology. In addition, it identifies the production technology, provides quantitative information about raw materials, processing, marketing and final consumption of products.

F) Economic analysis of the value chain. This complex of analysis evaluates the system for creating added value, product distribution based on quantitative indicators. Economic analysis provides an estimate of the gross value in the value chain. At the same time, the amount of added value is estimated for each chain and for each participant. The analysis provides for the assessment of value added in the context of production factors. What matters most in the analysis is the activities of private intermediaries in the value chain, who use market prices and consumer attitudes, that is, reference prices. This means that economic analysis should be carried out on a cost-utility basis.

\section{RESULTS AND RECOMMENDATIONS}

Comparison of the above two methodological approaches to the study and analysis of the value chain in the food industry allowed us to highlight the following most important and useful analysis methods for practical application. In doing so, attention should be paid to the following three most significant problems of the food industry value chain:

A) Study of the effect of market concentration, that is, the volume of production and sales in the food industry, the number of competitors, their market share, as well as important indicators that characterize the industry;

B) The process of creating the value of enterprises that manufacture products in the industry, their competitive advantages and characteristics;

C) Segmentation of the market by manufacturers-enterprises and its influence on the formation of $a$ competitive strategy.

The reason for choosing the above approach is that in order to assess the competitiveness of an enterprise in the value chain of the food industry, it is necessary to take into account the following analysis methods:

- Analysis of the intrinsic value of the enterprise. This type of analysis is used to determine the source and relative positions of value in the value creation process;

- Analysis of internal differentiation. This type of analysis is required to identify the sources of internal product differentiation in a value chain system;

- Analysis of the vertical dependence system. This type of analysis is needed in order to reduce the value of the product, which reaches the consumer, that is, for which people pay money. This should allow you to reduce the amount of cost (expenses) and get more profit. 
This type of analysis is beneficial to everyone, since the analysis focuses on the internal operations of firms. Based on this, in the next stage, attention is paid to competitive positions. Thus, a value chain approach to competitiveness is an integral part of strategic planning.

\section{CONCLUSIONS}

Based on the above theoretical materials on the management of competitiveness in the value chain of the food industry, the following conclusions can be drawn:

- To assess each value chain, firms must load production capacities at a sufficient level. If long-term levels of capacity utilization differ greatly from the planned one, you will have to look for more reliable sources of information to determine the sensitivity of the analysis results to changes in production volumes. After completing this type of task, enterprise managers should prioritize tasks to make positive changes in the value creation process. At the same time, enterprises must learn the factors that form the value of competitors in order to determine the price advantage;

- Enterprise accountants may have detailed information on costs in the process of creating product value, however, they do not always have information on individual sources of costs, which are a serious source of value. The use of only information that reflects the volume of production (unit of production, working hours, sales volume, etc.) can lead to errors in the calculation. In such cases, multiple creators can provide useful information on the cost structure;

- The constituent elements of the production cost may change. For example, the elements of execution reflect the operational decisions of the enterprise, showing effective methods that allow you to achieve the desired result. It is defined through the policy, culture and methods of the enterprise about management;

- Some elements of the cost of production in practice can be attributed to the operational level, when the cost analysis is carried out by the managers of the company. However, one should not forget that the elements of the cost of a product provide valuable information for making a strategic decision. The reason for this is that businesses use in the process of manufacturing products to proceed from their actions or operations to create value. And this allows them to understand the essence of the concept of the "resourcecost" proportion.

The practical application of the above analysis methods to study the value chain in the food industry will make it possible to achieve competitiveness not only by increasing production volumes, but also by creating a system for determining the value of products based on the desire and persistence of consumers. This will allow us to develop an "effective competition policy", to be well prepared for competition in the market, where external manufacturers are expected to appear in the near future.

\section{REFERENCES}

1. Alimova, G. A. (2020). Foreign Experience In Indexing The Amount Of Pensions. The American Journal of Social Science and Education Innovations, 2(11), 472-477.

2. Alimova, G. A. (2020). Increasing The Effective Use Of Human Capital In The 
Digital Economy. The American Journal of Applied sciences, 2(11), 127-130.

3. Muftaydinov K. (2020). Factors changing and influencing the investment climate in the of Uzbekistan. TRANS Asian Journal of Marketing \& Management Research (TAJMMR), (pp. 39-43).

4. Sotvoldiev, A. A. (2021). Innovation Aspects Modeling And Realization Regional Investment Projects. The American Journal of Interdisciplinary Innovations and Research, 3(01), 70-75.

5. Umarov, I. Y. (2019). SOCIAL AND ECONOMIC ESSENCE AND MAIN OBJECTIVES OF FOOD MARKET. In WORLD SCIENCE: PROBLEMS AND INNOVATIONS (pp. 121-123).

6. Umarov, I. Y. (2021). Ways To Develop Entrepreneurship In The Food Industry. The American Journal of Applied sciences, 3(01), 148-153.

7. Umarov, I., \& Rakhmanov, M. (2021). THE IMPACT OF DIGITAL ECONOMY ON THE DEVELOPMENT OF SMALL BUSINESS AND PRIVATE ENTREPRENEURSHIP. East European Scientific Journal, 3(2 (66)), 4-7.

8. Муфтайдинов, К. (2020). ОЦЕНКА ИНВЕСТИЦИОННОЙ ПРИВЛЕКАТЕЛЬНОСТИ ПРЕДПРИЯТИЯ. Экономика И социум, (7), 604-609.

9. Нурматов, А. Н., \& Абдуллаев, М. Г. (2014). ЭФФЕКТИВНЫЕ ПУТИ ЗАНЯТОСТИ НАСЕЛЕНИЯ. Журнал научных публикаций аспирантов и докторантов, (2), 32-33.

10. Умаров, И. Ю., \& Хусанова, З. Р. (2019). ПРИМЕНЕНИЕ ИННОВАЦИОННОЙ ДЕЯТЕЛЬНОСТИ В ПИЩЕВОЙ ПРОМЫШЛЕННОСТИ-КАК ФАКТОР ПОВЫШЕНИЯ УРОВНИ ЖИЗНИ НАСЕЛЕНИЯ. In Материалы VII
Международной научно-практической конференции «Актуальные проблемы социально-трудовых отношений», посвященной 6о-летию основания Института социально-экономических исследований ДФИЦ РАН (рp. 367-369).

11. Фарфиева, К. А. (2019). Роль третьего сектора в формировании и развитии гражданского общества в Узбекистане. European science, (3 (45)). 